\title{
The Ancient River System of the Kalahari and the Possibility of its Renewal.
}

\author{
By Prof. J. W. Gregory, F.R.S.
}

MANY arid countries contain wide mud-floored depressions which mark the sites of former lakes. This origin is so obvious that, as in western Australia, they are called lakes, although waterless. In South Africa they are known as vleis or pans. In a paper on the dry-lake system of West Australia in rgr4, I pointed out that the steady descent in level from one of these mud-flats to the next and their arrangement on converging lines indicates that the lakes are isolated sections of an ancient river system, which was broken up as the dwindling streams failed to keep open their channels. The same explanation gives the clue to the distribution of corresponding basins in Libya. Prof. E. H. L. Schwar\% has adopted the same idea for the great pans and vleis in the interior of southern Africa. He represents the Atosha Pan, the basins of Lake Ngami and Makarikari, and two lines of depression across the Kalahari desert, as remnants of one great river system which had its sources in the highlands of southern Angola. Its headstreams, including the Chobi and the Okavango, flowed south-eastward, parallel to the present course of the Upper Zambezi. The river was diverted southward by the highlands of southern Rhodesia and the Transvaal, and discharged to the Atlantic through the Orange River.

Prof. Schwarz holds it possible to restore the rivers in these depressions and thus refertilise the deserts between the Zambezi and the Orange River. According to his theory, the country has withered into desert by a process which is acting upon the whole of Africa. As the rivers cut their way through the rim of the African plateau they drain the interior, and thus cause the desiccation of the country. The rivers which are now the western tributaries of the Upper Zambezi have been cut off from the Kalahari region by a valley in line with the part of the Zambezi near the Victoria Falls. Prof. Schwarz's scheme is to build a weir across the Chobe Valley near its junction with the Zambezi and thus divert its water back through the old channels into Lake Ngami and Makarikari. These basins would become great lakes with an overflow across the Kalahari and through the Malopo to the Orange River. It is claimed that this change would render possible the irrigation of large tracts of country and profoundly modify the climate of South Africa. In a new paper, "The Kalahari Scheme as the Solution of the South African Drought Problem " (South African Journal of Science, xx., I923, pp. 208-222), Prof. Schwarz directs attention to the support to his proposals given by some great floods since the publication of his book "The Kalahari."

As an explanation of the distribution of the ancient lake basins of South Africa, Prof. Schwarz's theory seems fully trustworthy ; but the evidence he adduces for the recent desiccation of Africa is doubtful, and the meteorological foundations of his estimates as to the practical results of his proposed weir are highly speculative. The old river system was perhaps much earlier than Prof. Schwarz considers, and the building of a roo,oool. dam across the Chobe Valley might not revolutionise the climate of South Africa. Prof.
Schwarz estimates, especially from observations on the Tarka River, that 75 per cent. of the South African rainfall is derived from evaporation on the land, and only a quarter of it comes in from the ocean. As most of the South African rain occurs between October and March, when the prevalent winds are from the southeast, and most of it falls on the eastern half of the country, this estimate of the proportion of rain derived from the oceans appears unduly low. The benefit of the scheme to the South African climate is based partly on the effect of water lost from lakes by seepage ; for it is suggested that the water which percolates into the ground around the lakes would travel for long distances and raise the level of the ground-water throughout South Africa, and give that region a more humid climate.

Some of the meteorological facts are inconsistent with the generally accepted records. Thus it is said " that in the Fens, which are the wettest portion of England, the rainfall ranges from $I_{5}$ to $I_{2}$ inches a year." Unless the term wet is used here in some special sense, the statement would be denied in the Lake District, while Spurn Head and mid-east Essex, rival claimants for the minimum British rainfall, would unite in scepticism of the reported 12 -inch rainfall in the Fens. Another statement that may excite meteorological incredulity is the explanation of the rainfall around the Great Lakes of America by the fact that " every household pours immense volumes of watervapour into the air from kettles and pots, and steamengines and railway engines do the same; all this is available for precipitation as rain when atmospheric conditions are favourable." Equally uncertain is his argument from the classical Silphium. According to Prof. Schwarz, all Africa has undergone recent desiccation, and he accepts the view that northern Africa has become much drier since classical times. He dismisses the evidence from the distribution of the vine and the fruiting of the date-palm against any material climatic change around the eastern Mediterranean during the historic period, on the ground that these plants have been artificially preserved. $\mathrm{He}$ attaches more weight to the dubious plant Silphium, the evidence of which would be more trustworthy if it had not been artificially exterminated. He accepts its identification as Thapsia garganica, and holds that it has changed its habitat with the spread of desert vegetation over the once fertile fields of Cyrenaica.

If Silphium be Thapsia garganica, the plant has changed its secretions, which are very poisonous to camels and yield a powerful irritant. Silphium was highly prized as a universal medicine, as a condiment, in perfumery, and was a favourite food. It was probably exterminated by over-collecting. Pliny stated that it was extinct in Cyrenaica, the last plant found there being sent as a curiosity to the Emperor Nero. Thapsia garganica has been identified with it as the local plant most similar to the representations of Silphium on the Greek coins. The identification accepted by Prof. Schwarz, however, is directly opposed to his conclusions. His case is that Silphium now 
grows in the Garden of the Hesperides, whereas in ancient times it grew only in the far southern deserts, the flora of which has therefore spread northward. Pliny, however, mentioned the plant as found in the Garden of the Hesperides, and Thapsia garganica grows abundantly in the very area where the main supply of Silphium was found. Hence the identity of these plants would support the view that there has been no climatic change and no shift of vegetation in Cyrenaica since classical times.

The weakness of some of Prof. Schwarz's arguments does not necessarily invalidate his scheme, and it is to be hoped that they will not prevent its full investigation. He draws a gloomy picture of parts of the Karroo and southern Free State, which he says "are becoming depopulated owing to droughts " ; thousands of children are growing up under semi-starvation, and he predicts that fifty years hence, when the minerals have been depleted, "the enormous debt of the country will fall upon the shoulders of the impoverished sons of the soil, the Poor Whites will form the greater part of our population, and the country will be ruined." $\mathrm{He}$ attributes these changes to "a dwindling rainfall, a country becoming uninhabitable from droughts." Whether the Chobe Dam would directly improve the climate of the southern Free State and Cape Colony seems doubtful ; but it might be of great benefit to the northern regions if there be adequate population to till the irrigable land. It is probable that some of the flood water which flows wasted down the Zambezi could be diverted westward into the now arid basins of Ngamiland; but the data are inadequate to show how far south its influence would extend. In the interests of the northern arid areas of the Union of South Africa, it is to be hoped that study of the problem will be continued to demonstrate the extent of the area which would benefit by Prof. Schwarz's ingenious scheme.

\section{Obituary.}

Prof. W. Jack, LL.D., D.Sc.

DROF. WILLIAM JACK, whose death on March 20 , at his residence, 5 St. John's Terrace, Hillhead, Glasgow, was announced in NATURE of March 29, was born at Stewarton, Ayrshire, on May 29, I834. As a pupil in Irvine Academy he showed marked ability, and when he passed on to Glasgow University he confirmed the promise of his schooldays by taking a leading position in all the classes of the Faculty of Arts. In the Scottish Universities of that day there was little specialisation; all the students in the Arts Faculty followed the same curriculum and, as they usually entered the University comparatively young, the education they received formed a good foundation for the specialised studies of later life. For such more advanced studies, however, there was little direct provision in the University, and Jack, after graduating in Glasgow, proceeded to Cambridge, where he entered at Peterhouse. In the Tripos of 1859 he was fourth wrangler, but though he missed the coveted position of senior wrangler, he won the distinction of first place for the Smith's Prize. In I860 he was elected a fellow of Peterhouse. The sound general training of the Arts curriculum in Glasgow, followed by the specialisation at Cambridge, was an admirable preparation for a varied and successful career.

In 1860 Jack was appointed one of Her Majesty's Inspectors of Schools in Scotland; in the south-west district to which he was assigned he won the esteem of the schoolmasters, and he is gratefully remembered by the small band of survivors. In 1866 he resigned the inspectorship to take up the duties of the chair of natural philosophy at Owens College, Manchester. There he took an active part not merely in the work of the College but in the general life of the community, and he was gratified by the recognition of his services on the occasion of the jubilee celebrations in 1902 , when the Victoria University conferred on him the degree of D.Sc.

It might have seemed as if Prof. Jack had withdrawn from educational work when in 1870 he accepted the position of editor of the Glasgow Herald; yet it is unquestionable that one of the chief reasons that induced him to accept that position was of a definitely educational kind. One of his main objects, as he told his staff, was to make the newspaper a "people's university," and in pursuance of this aim reviews of books received much more attention and the area of its news service was much extended. At the present day the Glasgow Herald holds a leading position for the quality of its literary articles. Jack continued as editor until 1876 , when he became associated with the firm of Messrs. Macmillan and $\mathrm{Co}$.

Prof. Jack's most notable services to the cause of education, however, were rendered during his occupancy of the chair of mathematics in the University of Glasgow, to which he was appointed in 1879 . His accession was marked by a thorough reorganisation of the mathematical department. At the date of his election the curriculum for degrees in Arts made little provision for advanced study, the course of study was rather narrow, and too frequently the classes were overcrowded. While preserving the essential features of the recognised courses he greatly improved the efficiency of the teaching by well-designed subdivisions of the classes, introduced in certain cases the element of tutorial instruction, and, by the institution of higher courses, extended the range and raised the standard of the honours degree. A new spirit was awakened among the students, and showed itself not merely in the increased attendance on the advanced classes, but also in the importance attached to the work of the summer vacation. At that time there was no summer session in the Faculty of Arts, but under his direct encouragement, and with his substantial support, summer classes were formed for the study of branches of higher mathematics that could not be overtaken in the winter session, and these classes became a feature of the mathematical teaching. The great improvement of the position of mathematics in the schools and universities of Scotland that marked the closing years of last century was due in no small degree to Prof. Jack's labours.

Prof. Jack won the affection of his students. Even the dullest member of the junior class felt the influence of the genial nature that could not be curbed by the

$$
\text { NO. } 284 \text { I, VOL. I I } 3 \text { ] }
$$

